\title{
Litterfall nutrient return in thinned young stands with Douglas fir
}

\author{
Jiří Novák*, Dušan Kacálek, David Dušek \\ Forestryand Game Management Research Institute, Research Station at Opočno, Na Olivě 550, CZ-517 73 Opočno, Czech Republic
}

\begin{abstract}
The use of Douglas fir (DF) is on the increase in the Czech Republic. This tree species shows a good production and also a beneficial impact on soil to some extent. We studied both amount and properties of litterfall in 18 to 20 -year-old stands with DF in 2011. Two experimental plots were DF-dominated and one showed ca. 20 - 30\% share of Scots pine (SP) at the beginning of observation. The experiments consisted of two treatments such as unthinned control and $50-62 \%$ trees' density reduction accounting for $43-59 \%$ basal area reduction. Litterfall was collected using litter traps of $0.25 \mathrm{~m}^{2}$ area in 3-4 traps per treatment. Forest floor $\mathrm{L}$ and $\mathrm{F}$ were taken in 2011 and 2018 to investigate the development of their amount after thinning. Both whole-period sum and mean annual litterfall were reduced after thinning compared to controls. The mean annual litterfall totaled ca. $3 \mathrm{t} \mathrm{ha}^{-1}$ in 20 -year-old DF-dominated stands. This amount represents an annual nutrient return of $30-40 \mathrm{~kg} \mathrm{~N}, 1-3 \mathrm{~kg} \mathrm{P}, 3-5 \mathrm{~kg} \mathrm{~K}, 12-30 \mathrm{~kg} \mathrm{Ca}$ and $1-2 \mathrm{~kg}$ $\mathrm{Mg}$ per one hectare. The reduction of the annual litterfall was more pronounced in DF-dominated stands. All thinned plots showed increased decomposition rates reflected in lower total $\mathrm{L}+\mathrm{F}$ amounts in both DF-dominated plots whereas unthinned plots accumulated more $\mathrm{L}+\mathrm{F}$ at the end. The mixed DF-SP plot showed reduced $\mathrm{L}$ and increased $\mathrm{F}$ layer amounts in both unthinned and thinned treatments with only minor change to $\mathrm{L}+\mathrm{F}$ sum between 2011 and 2018 .
\end{abstract}

Key words: litterfall; forest floor; thinning; nutrients; Douglas fir

Editor: Bohdan Konôpka

\section{Introduction}

Forest ecosystems face both climate changes and various levels of anthropogenic disturbance. At many sites, Norway spruce stands exhibit a die-off due to lack of precipitation and following bark beetle outbreak. Foresters are, therefore, forced to find new silviculture approaches frequently; for example tree species conversion. At many sites, domesticated non-native trees such as Douglas fir (hereinafter referred to as DF), which have proved their capabilities, are beneficial. Although DF has been connected with central European forestry for more than hundred years, only several thousand hectares are managed ( $0.28 \%$ of current species composition) in the Czech Republic. This situation is likely to be attributable to fear of wider use of non-native tree species. However, the risk of wrong decision is minimized by intensive research and long-term verification of recommended silvicultural measures in forest practice in the last decades.

Besides its outstanding production (Kantor et al. 2001; Podrázský et al. 2013), also soil improving effects of litterfall were observed (Thomas \& Prescott 2000;
Podrázský \& Remeš 2005, 2008; Podrázský \& Kupka 2011; Ulbrichová et al. 2014) compared to other conifers. Although some information on accumulation and decomposition of DF litterfall have been published (Menšík et al. 2009; Podrázský et al. 2009), long-term investigation into year-by-year amounts and quality of litterfall including its relation to thinning were needed. In the Czech Republic, the use of DF is a rising issue which is reflected in number of projects (Kubeček et al. 2014; Slodičák et al. 2014) and resulted in establishment of many experimental plots. Thinning improves stands' stability (e.g. Settineri et al. 2018) and reduces stress resulting from overstocking (Chase et al. 2016) which can lead to a greater mortality during the decline events such as drought (Livingston \& Kenefic 2018). Thinning can also help improve microbial conditions in organic horizons such as L and F (Wang et al. 2019).

The objectives of this study was to monitor litterfall amounts changes after thinning and analyze its nutrient contents in order to estimate an impact of thinning on nutrient return over longer time compared to previously published studies. 


\section{Material and methods}

Three thinning experiments with DF were established in spring 2011 (Table 1) in 18 to 20 -year-old stands. DF dominated in the species compositions totally (Obo) or other species were admixed - mainly Norway spruce or Scots pine in the experiment Pol1 or Pol2, respectively. Stands were established by artificial (Obo) and natural (Pol1 and Pol2) regeneration. All sites are located in the Eastern part of Bohemia and belong to Colloredo-Mansfeld family estate. Mean annual temperature is $9.6{ }^{\circ} \mathrm{C}$ and mean annual amount of precipitation is $520 \mathrm{~mm}$ in the region of interest.

Each experiment consisted of two plots (with area of $0.04 \mathrm{ha}$ ), one was control unthinned stand and second one was managed using a very heavy thinning from below (Fig. 1). Thinning intensity was $62 \%$ on the basis of number of trees $(\mathrm{N})$ and $59 \%$ on the basis of removed basal area (G) in Pol1. Two thinnings were done in Pol2. First at the start of observation period ( $50 \%$ of N and $49 \%$ of $\mathrm{G}$ removed) and second was realized 7 years later at the age of 24 years ( $24 \%$ of $\mathrm{N}$ and $43 \%$ of $\mathrm{G}$ removed). On the experiment Obo, $57 \%$ of $\mathrm{N}$ representing $43 \%$ of $\mathrm{G}$ was removed by first thinning at the age of 20 years.

Litterfall was collected using 3 - 4 litter traps (with an area of $0.25 \mathrm{~m}^{2}$ each) per partial plots installed within stands in February (Obo) and October (Pol1, Pol2) 2011. The samples were taken twice to fourth times per year until October 2018.

At both the beginning (autumn 2011) and the end (autumn 2018) of observation period, forest-floor humus horizons (data from $\mathrm{L}=$ fresh litter and $\mathrm{F}=$ fermented layer were analyzed in this study) were investigated quantitatively in comparative plots $(\mathrm{C}-$ control and $\mathrm{T}$ - thinned) of all experiments. The samples were taken using steel frames $(25 \times 25 \mathrm{~cm})$ to demarcate an area for collecting all enclosed material. Comparative plots and also observed stands are relatively small and homogenous. Nevertheless, the number of samples was gradually increased (three samples per plot in 2011 and six samples per plot in 2018).

All samples were dried, first under conditions of open air, later in a laboratory oven at $80^{\circ} \mathrm{C}$, and dry samples were subsequently weighed. Nutrient content in litterfall was assessed from composite samples from each comparative plot (after mineralization by mineral acids). Total nitrogen concentration was analyzed using Kjehldahl procedure and phosphorus concentration was determined colorimetrically. An atomic absorption spectrophotometer was used to determine total potassium concentration by flame emission, and calcium and magnesium by atomic absorption after addition of lanthanum. Data were analyzed using a descriptive statistics and we use paired t-test for total litterfall samples from three control and thinned plots.

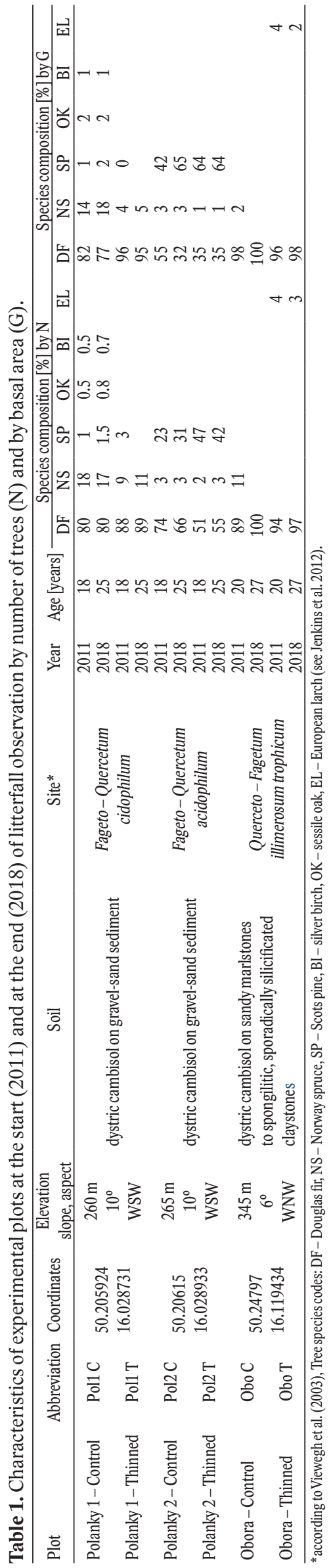




\section{Results}

Thinning regimes (Fig. 1) led to lower amounts of annual litterfall in DF-dominated plots Pol1 and Obo compared to unthinned control (Fig. 2). As for the whole-period, total sums of litterfall were also reduced between 2011 - 2018; the thinned treatment values were found to be close to those of control values in mixed DF-SP plot Pol2 (Table 2). The reduction amounted to $1.2 \mathrm{t}$ (5\%) whereas both DF-dominated plots showed even less dry mass amounting 3.9 (8\%) and 6.0 t (10\%) in Pol1 and Obo plots respectively. Mean annual litterfall was $170 \mathrm{~kg}$ lower in Pol2, $563 \mathrm{~kg}$ in Pol1 and $773 \mathrm{~kg}$ in Obo compared to their unthinned treatments. Differences (long-term lower amount of litterfall under thinned stands compared control stands) were $15 \%$ (p-value 0.10 ).

The less dry mass return the lower nutrient return. The only slightly higher $\mathrm{N}$ and $\mathrm{P}$ return in thinned Pol2 (Fig. 3) was found due to slightly higher, though insignificantly, concentrations of these nutrients. As for the litterfall nutrient concentrations, $\mathrm{N}$ oscillated between $0.8-1.3 \%$-, Ca $0.4-0.8 \%$-, P $0.04-0.10 \%$, K 0.09 $-0.16 \%$ and $\mathrm{Mg} 0.04$ to $0.06 \%$ which accounted for an

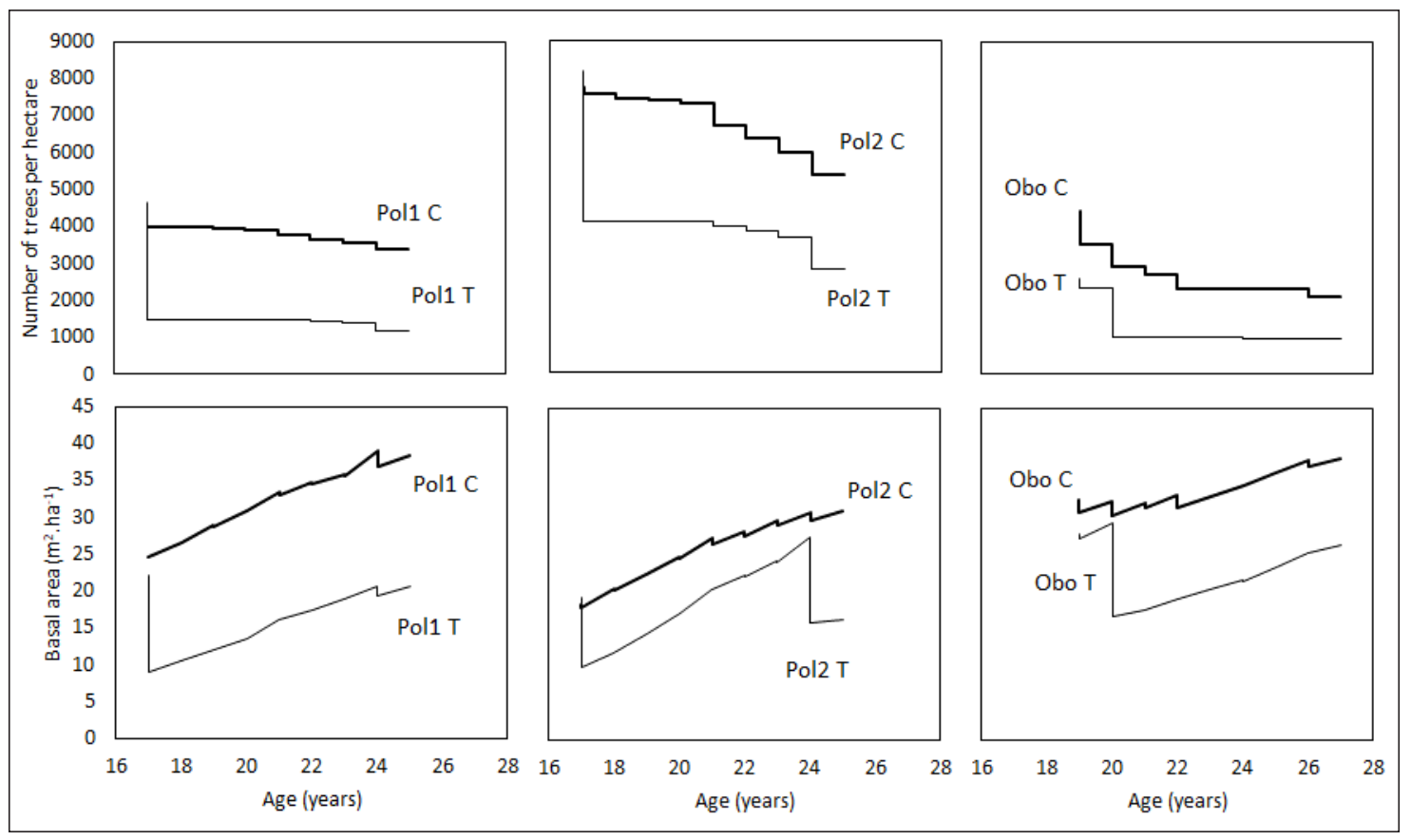

Fig. 1. Number of trees (above) and basal area (below) on experimental plots with litterfall observation (for plot designation see Table 1).

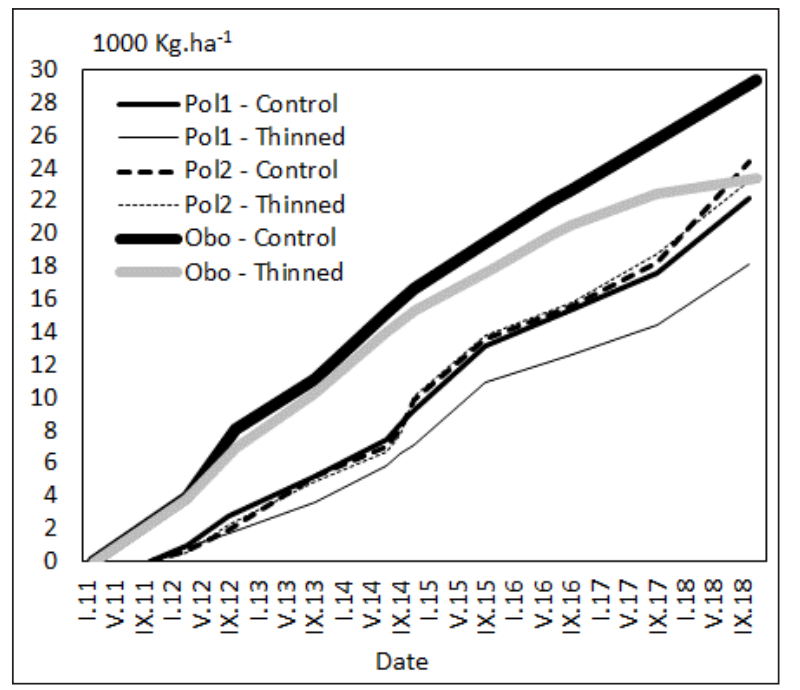

Fig. 2. Cumulative amount of litterfall dry mass in the period between 2011 - 2018 (for plot designation see Table 1). annual litterfall return amounting $30-50 \mathrm{~kg}$ of N, $2-3$ $\mathrm{kg}$ of P, 3-5 $\mathrm{kg}$ of K, $12-30 \mathrm{~kg}$ of $\mathrm{Ca}$ and $1-2 \mathrm{~kg}$ of $\mathrm{Mg}$ per one hectare of young DF-dominated young stands (Table 2).

We also observed, that litterfall turnover under young DF stands was relatively fast (Fig. 4). Although litterfall amounted 20 - 30 t per hectare (Fig. 4) between 2011 and 2018, dry mass of forest floor horizons L+F of only two control plots (Pol1 and Obo) was ca 4 t per hectare higher compared to the thinned treatments. Effect of thinning was observed on the upper forest floor layers as all thinned plots showed increased decomposition rates reflected in lower total $\mathrm{L}+\mathrm{F}$ amounts in both DFdominated plots and also in reduced $\mathrm{L}$ and increased $\mathrm{F}$ layer in the mixed DF-SP Pol2 plot (Fig. 4). 
Table 2. Amount of dry-mass and nutrients in litterfall under young Douglas-fir stands (for plot designation see Table 1).

\begin{tabular}{|c|c|c|c|c|c|c|c|}
\hline & \multirow{2}{*}{ Plot } & \multirow{2}{*}{ Dry mass } & \multicolumn{5}{|c|}{ Nutrients } \\
\hline & & & $\mathrm{N}$ & $\mathrm{P}$ & $\mathrm{K}$ & $\mathrm{Ca}$ & $\mathrm{Mg}$ \\
\hline \multirow{6}{*}{$\begin{array}{l}\text { Amount for observation period } 2011-2018 \\
{\left[\mathrm{~kg} \mathrm{ha}^{-1}\right]}\end{array}$} & Pol1 C & 22121 & 293.0 & 20.4 & 30.5 & 103.0 & 14.0 \\
\hline & Pol1 T & 18177 & 220.3 & 13.7 & 25.3 & 84.4 & 11.8 \\
\hline & Pol2 C & 24419 & 188.0 & 10.6 & 29.9 & 112.2 & 12.4 \\
\hline & Pol2 T & 23227 & 209.5 & 11.9 & 22.4 & 86.3 & 9.5 \\
\hline & Obo C & 29373 & 394.0 & 26.9 & 41.8 & 240.7 & 16.3 \\
\hline & Obo T & 23383 & 312.4 & 21.2 & 30.5 & 165.8 & 12.1 \\
\hline \multirow{6}{*}{$\begin{array}{l}\text { Amount for mean annual litterfall } \\
{\left[\mathrm{kg} \mathrm{ha}^{-1}\right]}\end{array}$} & Pol1 C & 3160 & 41.9 & 2.9 & 4.4 & 14.7 & 2.0 \\
\hline & Pol1 T & 2597 & 31.5 & 2.0 & 3.6 & 12.1 & 1.7 \\
\hline & Pol2 C & 3488 & 26.9 & 1.5 & 4.3 & 16.0 & 1.8 \\
\hline & Pol2 T & 3318 & 29.9 & 1.7 & 3.2 & 12.3 & 1.4 \\
\hline & Obo C & 3790 & 50.8 & 3.5 & 5.4 & 31.1 & 2.1 \\
\hline & Obo T & 3017 & 40.3 & 2.7 & 3.9 & 21.4 & 1.6 \\
\hline
\end{tabular}
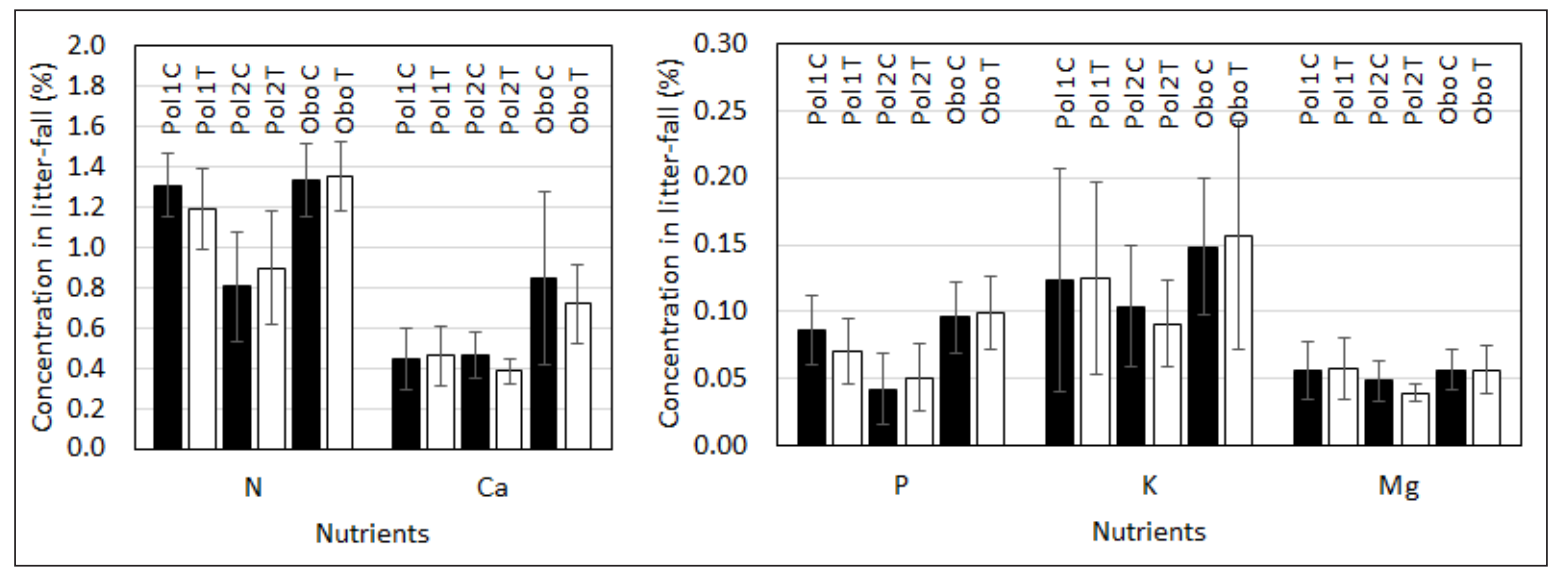

Fig. 3. Concentrations (mean with S.D.) of nutrients (left $-\mathrm{N}$ and $\mathrm{Ca}$, right $-\mathrm{P}, \mathrm{K}$ and $\mathrm{Mg}$ ) in litterfall under young Douglas-fir stands (for plot designation see Table 1).

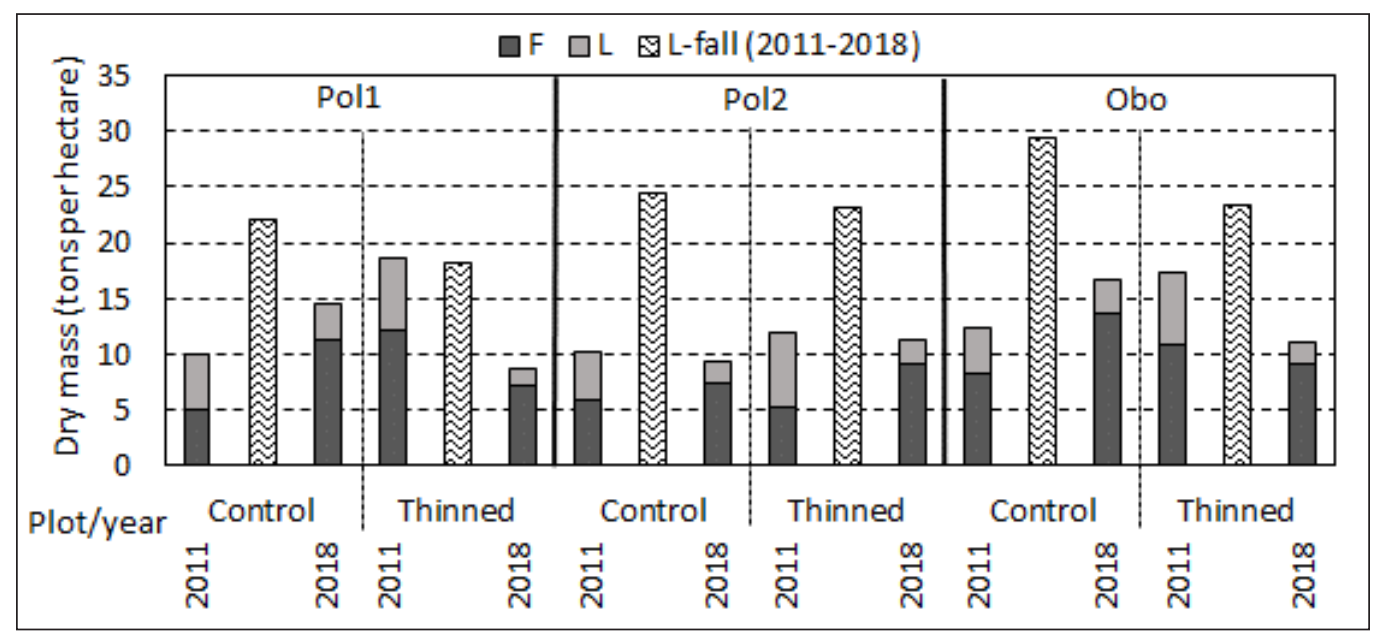

Fig. 4. Change of dry-mass accumulation in horizons $\mathrm{L}$ and $\mathrm{F}$ under differently thinned young Douglas-fir stands in connection with litterfall dry mass for the same period (for plot designation see Table 1).

\section{Discussion}

As for the DF litterfall amount, 20-year-old stands were reported as shedding between 1.4 and $2.5 \mathrm{tha}^{-1}$ of dry mass annually (Turner \& Long 1975; Binkley et al. 1984). In 40-year-old and older stands, annual dry mass litterfall ranged between $1.4-3.5 \mathrm{t} \mathrm{ha}^{-1}$ (Will 1959; Mcshane et al. 1983; Fried et al. 1990; Longdoz et al. 2000; Berg et al. 2001). This, however, does not mean that litterfall increase mainly with the age. On the other hand the litterfall seems to be strongly related to basal area (Novák et al. 2014) which increases with the age; $G$ is also strongly related to the total stand biomass of DF (Ponette et al. 2001). Besides $G$, also other stand production characteristics such as wood volume, above-ground biomass and mean annual increment correlated strongly with mean annual litterfall (Erkan et al. 2018). Maguire (1994) reported more released necromass through branch mor- 
tality from larger DF trees and denser plots with DF. In our 17 - 25-year-old experiments, the annual litterfall amounted to ca. $3 \mathrm{t} \mathrm{ha}^{-1}$ which was attributable to differences in stand density and G. For example Turner \& Long (1975) reported $1.4 \mathrm{t} \mathrm{ha}^{-1}$ litter that fell off annually from the 23 -year-old, thinner (650 trees ha-1) stand with $\mathrm{G}$ amounting $9.7 \mathrm{~m}^{2} \mathrm{ha}^{-1}$ whereas 22-year-old, much denser $\left(2756\right.$ trees ha $\left.^{-1}\right)$ stand with higher G $\left(42 \mathrm{~m}^{2} \mathrm{ha}^{-1}\right)$ showed $2.5 \mathrm{t} \mathrm{ha}^{-1}$ of litterfall (Binkley et al. 1984).

Although differences among tree species litterfall have been described (e.g. Augusto et al. 2002). Observed amounts of DF litterfall are consistent with those ones shown in the Czech native commercial conifers (Kacálek et al. 2018). It is also in accordance with Hansen et al. (2009), who reported no significant differences among litterfall amounts of tree species such as Norway spruce, Sitka spruce, Douglas fir, European beech and common oak in common garden experiment in Denmark. Hansen et al. (2009) concluded that previously reported large variability in forest floor accumulation should primarily be attributed to differences in litter decomposition.

The monitoring time span is a crucial prerequisite for getting reliable data as year-on-year amounts of fallingoff litter vary which is confirmed e.g. by Will (1959) or Trofymow et al. (1991). The fluctuating values are also attributable to climate oscillations. As for the annual nutrient return, our values amounting ca. $30-50 \mathrm{~kg} \mathrm{~N}$, $1-3 \mathrm{~kg} \mathrm{P}, 3-5 \mathrm{~kg} \mathrm{~K}, 12-30 \mathrm{~kg}$ Ca a $1-2 \mathrm{~kg} \mathrm{Mg}$ are similar to ranges reported for DF stands by other authors (Will 1959; Turner 1981; Fried et al. 1990; Trofymow et al. 1991). The litterfall amount itself is not, however, the most important from forest nutrition point of view. Density reduction of stands with higher basal area would result in more water available for trees and also in higher nutrient release (or lower nutrient immobilization) from decomposing needle litter (Bueis et al. 2018) which is a positive effect to the site though the total amounts of litter are reduced.

Thinning reduces litterfall amount (del Río et al. 2017) as the stand density is controlled deliberately. This can be expected if the pre-thinned stands are homogeneous. Accordingly, we observed higher differences (lower litter-fall due to thinning) in DF-dominated plots (Pol1 and Obo) compared to plot Pol2 with higher initial density, higher share of other species (Scots pine) and lower thinning intensity (by $G$ ). The trees left on site use more light, additional water and more available nitrogen (Chase et al. 2016) to increase the diameter increment and enlarge crowns thus closing the canopy again which increases litterfall gradually (Roig et al. 2005; Erkan et al. 2018). Trofymow et al. (1991) reported 15-year reduction of DF litterfall after removal of $2 / 3$ of $G$ at the age of 25 years. DF old-growth stands are expected to reduce foliage due to humidity stress and severe air temperature which also reduces transpiration rate and increase soil moisture (Dong et al. 2018). Therefore, the role of thinning, which emulates natural loss of needles, is to help stands cope with the climatic extremes.
Our results did not confirm the fear of the excessive accumulation of raw litter in forest floor under DF-dominated stands. The upper two horizons $(\mathrm{L}+\mathrm{F})$ accumulated $9-19 \mathrm{t} \mathrm{ha}^{-1}$ of dry mass. Similar $\left(3-15 \mathrm{t} \mathrm{ha}^{-1}\right.$, Šarman 1982) and even higher (25-26 tha ${ }^{-1}$, Podrázský et al. 2006) results were reported for Norway spruce, or European beech where it amounted $14-18 \mathrm{t} \mathrm{ha}^{-1}$ (Podrázský \& Viewegh 2005). Relatively quick decomposition observed in our experiment was additionally accelerated by thinning (confirmed on two experimental plots with lower initial density, lower share of other species and higher thinning intensity). It was in accordance with results of Wright (1957) and Wilhelmi (1988) for Norway spruce or Blanco et al. (2008) for Scots pine. In those studies, there were reported greater both litterfall and forest floor accumulation in unthinned or in (only) light-thinned stands. How this effect is reflected in the stocks of nutrients in the forest floor und upper soil horizons, it needs further and more detailed research and we included it into following analyses in our experiments.

\section{Conclusion}

Young DF-dominated stands react to very heavy thinning by lower amount of litterfall and quicker rate of litter decomposition. This effect showed similar trend compared to native conifers (Norway spruce, Scots pine). Thus DF can be recommended as the commercial species in the Czech Republic conditions which do not pose any excessive risk if used as admixed species with native broadleaves or conifers.

\section{Acknowledgement}

Supported by the Ministry of Agriculture of the Czech Republic, institutional support MZE-RO0118.

\section{References}

Augusto, L., Ranger, J., Binkley, D., Rothe, A., 2002: Impact of several common tree species of European temperate forests on soil fertility. Annals of Forest Science, 59:233-253.

Berg, B., McClaugherty, C., De Santo, A. V., Johnson, D., 2001: Humus buildup in boreal forests: effects of litter fall and its $\mathrm{N}$ concentration. Canadian Journal of Forest Research, 31:988-998.

Binkley, D., Lousier, J.D., Cromack, K., 1984: Ecosystem effects of Sitka alder in a Douglas-fir plantation. Forest Science, 30:26-35.

Blanco, J. A., Imbert, J. B., Castillo, F. J., 2008: Nutrient return via litterfall in two contrasting Pinus sylvestris forests in the Pyrenees under different thinning intensities. Forest Ecology and Management, 256:1840-1852. 
Bueis, T., Bravo, F., Pando, V., Belén Turrión, M., 2018: Local basal area affects needle litterfall, nutrient concentration, and nutrient release during decomposition in Pinus halepensis Mill. plantations in Spain. Annals of Forest Science, 75:21.

Chase, Ch. W., Kimsey, M. J., Shaw, T. M., Coleman M. D., 2016: The response of light, water, and nutrient availability to pre-commercial thinning in dry inland Douglas-fir forests. Forest Ecology and Management, 363:98-109.

del Río, M., Bravo-Oviedo, A., Pretzsch, H., Löf, M., Ruiz-Peinado, R., 2017: A review of thinning effects on Scots pine stands: From growth and yield to new challenges under global change. Forest Systems, 26, 2:eR03S.

Dong, Z., Driscoll, Ch. T., Johnson, S. L., Campbell, J. L., Pourmokhtarian, A., Stoner, A. M. K. et al., 2019: Projections of water, carbon, and nitrogen dynamics under future climate change in an old-growth Douglas-fir forest in the western Cascade Range using a biogeochemical model. Science of the Total Environment, 656:608-624.

Erkan, N., Comez, A., Cem Aydin, A., Denli, O., Erkan, S., 2018: Litterfall in relation to stand parameters and climatic factors in Pinus brutia forests in Turkey. Scandinavian Journal of Forest Research, 33:338346.

Fried, J. S., Boyle, J. R., Tappeiner, J. C., Cromack, K., 1990: Effects of bigleaf maple on soils in Douglasfir forests. Canadian Journal of Forest Research, 20:259-266.

Hansen, K., Vesterdal, L., Schmidt, I. K., Gundersen, P., Sevel, L., Bastrup-Birk, A. et al., 2009: Litterfall and nutrient return in five tree species in a common garden experiment. Forest Ecology and Management, 257:2133-2144.

Jenkins, T. A. R., Gilbert, J., Mackie, E. D., Matthews, R.W., 2012: Tree Species, A document listing the tree species included in the 2011 Production Forecast. Forecast technical document, Forestry Comission, $7 \mathrm{p}$.

Kacálek, D., Novák, J., Dušek, D., Slodičák, M., 2018: Litter fall and forest floor under conifer stands: silviculture consequences - a review. In: A. C. Gonçalves: Conifers. IntechOpen, p. 77-89.

Kantor, P., Knott, R., Martiník, A., 2001: Production capacity of Douglas fir (Pseudotsuga menziesii [Mirb.] Franco) in a mixed stand. Ekológia (Bratislava), 20 (Suppl.), 1:5-14.

Kubeček, J., Štefančík, I., Podrázský, V., Longauer, R., 2014: Výsledky výzkumu douglasky tisolisté (Pseudotsuga menziesii [Mirb.] Franco) v České republice a na Slovensku - přehled. Lesnícky časopis-Forestry Journal, 60:116-124.

Livingston, W. H., Kenefic, L. S., 2018: Low densities in white pine stands reduce risk of drought-incited decline. Forest Ecology and Management, 423:8493.
Longdoz, B., Yernaux., M, Aubinet, M., 2000: Soil CO efflux measurements in a mixed forest: impact of chamber disturbances, spatial variability and seasonal evolution. Global Change Biology, 6:907-917.

Maguire, D. A., 1994: Branch mortality and potential litterfall from Douglas-fir trees in stands of varying density. Forest Ecology and Management, 70:41-53.

Mcshane, M. C., Carlile, D. W., Hinds, W. T., 1983: The effect of collector size on forests litter-fall collection and analysis. Canadian Journal of Forest Research, 13:1037-1042.

Menšík, L., Kulhavý, J., Kantor, P., Remeš, M., 2009: Humus conditions of stands with the different proportion of Douglas fir in training forest district Hůrky and the Krrtiny Forest Training Enterprise. Journal of Forest Science, 55:345-356.

Novák, J., Dušek, D., Slodičák, M., 2014: Quantity and quality of litterfall in young oak stands. Journal of Forest Science, 60:219-225.

Podrázský, V., Čermák, R., Zahradník, D., Kouba, J., 2013: Production of Douglas-fir in the Czech Republic based on national forest inventory data. Journal of Forest Science, 59:398-404.

Podrázský, V., Remeš, J., 2005: Retenční schopnost svrchní vrstvy půd lesních porostů s různým druhovým složením. Zprávy lesnického výzkumu, 50:46-48.

Podrázský, V., Viewegh, J., 2005: Comparison of humus form state in the beech and spruce parts of the Žákova hora National Nature Reserve. Journal of Forest Science (Special Issue), 51:29-37.

Podrázský, V., Remeš, J., 2008: Půdotvorná role významných introdukovaných jehličnanů - douglasky tisolisté, jedle obrovské a borovice vejmutovky. Zprávy lesnického výzkumu, 53:27-34.

Podrázský, V., Moser, W. K., Novák, J., 2006: Changes in the quantity and characteristics of surface humus after thinning treatments. Scientia Agriculturae Bohemica, 37:25-28.

Podrázský, V., Remeš, J., Hart, V., Moser, W. K., 2009: Production and humus form development in forest stands established on agricultural lands - Kostelec nad Černými lesy region. Journal of Forest Science, 55:299-305.

Podrázský, V., Kupka, I., 2011: Vliv douglasky tisolisté (Pseudotsuga menziesii [Mirb] Franco) na základní pedofyzikální charakteristiky lesních půd. Zprávy lesnického výzkumu, 56 (Special):1-5.

Ponette, Q., Ranger, J., Ottorini, J.-M., Ulrich, E., 2001: Aboveground biomass and nutrient content of five Douglas-fir stands in France. Forest Ecology and Management, 142:109-127.

Roig, S., del Río, M., Cañellas, I., Montero, G., 2005: Litter fall in Mediterranean Pinus pinaster Ait. stands under different thinning regimes. Forest Ecology and Management, 206:179-190. 
Settineri, G., Mallamaci, C., Mitrović, M., Sidari, M., Muscolo, A., 2018: Effects of different thinning intensities on soil carbon storage in Pinus laricio forest of Apennine South Italy. European Journal of Forest Research, 137:131-141.

Slodičák, M., Novák, J., Mauer, O., Podrázský, V. et al., 2014: Pěstební postupy při zavádění douglasky do porostních směsí v podmínkách ČR. Kostelec nad Černými lesy, Lesnická práce, 272 p.

Šarman, J., 1982: Vliv probírky na povrchový humus ve smrkovém porostu. Lesnictví-Forestry, 28:31-42.

Thomas, K. D., Prescott, C. E., 2000: Nitrogen availability in forest floors of three tree species on the same site: The role of litter quality. Canadian Journal of Forest Research, 11:1698-1706.

Trofymow, J. A., Barclay, H. J., McCullough, K. M., 1991: Annual rates and elemental concentrations of litter fall in thinned and fertilized Douglas-fir. Canadian Journal of Forest Research, 21:1601-1615.

Turner, J., 1981: Nutrient cycling in an age sequence of Western Washington Douglas-fir stands. Annals of Botany, 48:159-169.

Turner, J., Long, J. N., 1975: Accumulation of organic matter in a series of Douglas-fir stands. Canadian Journal of Forest Research, 5:681-690.
Ulbrichová, I., Kupka, I., Podrázský, V., Kubeček, J., Fulín, M., 2014: Douglaska jako meliorační a zpevňující dřevina. Zprávy lesnického výzkumu, 59: 72-78.

Viewegh, J., Kusbach, A., Mikeska, M., 2003: Czech forest ecosystem classification. Journal of Forest Science, 49:85-93.

Wang, L., Zhao, G., Sun, Y., Yang, Y., Zhou, H., 2019: Effects of Thinning on Microbial Community Structure in the Organic Horizon of Chinese Pine Plantations in Badaling, Beijing, China. Forests, 10:828.

Wilhelmi, V., 1988: Düngung und Durchforstung als kombinierte Waldsanierungsmaßnahme. Allgemeine Forstzeitschrift, 159:844-846.

Will, G. M., 1959: Nutrient return in litter and rainfall under some exotic conifer stands in New Zealand. New Zealand Journal of Agricultural Research, 2:719-734.

Wright, T.W., 1957: Some effects of thinning on the soil of a Norway spruce plantation. Forestry, 30:123-133. 